\title{
The Hirnantian (Late Ordovician) brachiopod fauna of the East Baltic: Taxonomy of the key species
}

\author{
Linda Hints and David A.T. Harper \\ Acta Palaeontologica Polonica 60 (2), 2015: 395-420 doi: http://dx.doi.org/10.4202/app.2013.0010
}

Rhynchonelliformean brachiopods, belonging to 17 genera, are described from the East Baltic Porkuni Regional Stage, correlated with the global Hirnantian Stage. The brachiopod genera Paromalomena, Proboscizambon ?, Kinnella, Drabo-via, and Coolinia, which are described from the region for the first time demonstrate together with characteristic Hir-nantian species of the genera Hirnantia, Dalmanella, Plectothyrella, Eostropheodonta, and Hindella a greater than pre-viously thought commonality of the Baltic fauna with the terminal Ordovician Hirnantia brachiopod fauna of the Kosov Province. The samples containing brachiopods were collected from 43 drill core sections in Central East Baltic. The study area belongs to the Livonian Tongue of the Central Baltoscandian Facies Belt in the Baltic Basin. The brachiopods occur mainly in the skeletal and silty limestone of the Kuldiga Formation within the lower half of the Porkuni Stage. Few brachiopods are known from the sandy or oolitic limestone of the Saldus Formation in the upper part of the stage. Due to excellent preservation some brachiopod species (e.g., Cliftonia psittacina and Dalmanella testudinaria) yield key morphological information, relevant to their classification and phylogeny. This taxonomic study of the East Baltic brachiopods presents essential groundwork for analysis in progress on the distribution and onshore-offshore successions of the Hirnantia brachiopod fauna within both a Baltoscandian and global context.

Key words: Brachiopoda, taxonomy, Ordovician, Hirnantian, East Baltic.

Linda Hints [Linda.Hints@ ttu.ee], Institute of Geology at Tallinn University of Technology, Ehitajate tee 5, 19086 Tallinn, Estonia; David A. T. Harper [david.harper@durham.ac.uk], Department of Earth Sciences, Durham University, Durham, DH1 3LE, UK. 
This is an open-access article distributed under the terms of the Creative Commons

Attribution License (for details please see creativecommons.org), which permits unrestricted use, distribution, and reproduction in any medium, provided the original author and source are credited.

FoF Full text $(2,429.5 \mathrm{kB})$ 